It may be remarked that Prof. D. M. S. Watson expressed grave doubts concerning the validity of the arguments used by some of the palæontologists who took part in the discussion. He especially deplored the use of ontogenetic evidence alone in the establishment of supposed phylogenies. $\mathrm{He}$ also criticised severely some current interpretations of the analyses of statistics relating to variability among invertebrate fossils, to which reference had been made.

In short, palæontologists are agreed as to the general extent and importance of the contributions of their subject to the solution of evolutionary problems; it is as regards the interpretation of the details of the evidence that there is much difference of opinion.

A. E. Trumman.

\title{
The Gene and the Theory of Living Structures.
}

$D^{\mathrm{R}}$

R. C. B. BRIDGES, whose name is associated with those of Morgan and Sturtevant in the now classical studies on the cytogenetics of Drosophila, and who recently went to Russia for a stay of some months, gave an address before the Genetical Society on Oct. 19, on the subject of "The Gene and the Theory of Living Structures".

Dr. Bridges led up to the question of the gene by a general discussion of scientific method. His general method of approach is an analysis from two aspects, that of structure and that of behaviour. This analysis is made at successively deeper levels, each simplification of the unit reducing complexity of structure; or, looking at it the other way, each change from a lower to a higher unit offering new possibilities of complexity not necessarily predictable at the lower level. Thus a crystal of sugar is successively analysable into sugar molecules, atoms arranged in a definite space-lattice, electrons, etc., composing the respective atoms. Reversing the process, the electrons must have preceded the atoms, the atoms the molecules, thus giving rise to evolution by progressive stages of aggregation, each stage presenting a fresh type of complexity. This might be called a form of the doctrine of emergent evolution, only the emergence is as true in the case of nonliving as of living things. Of course, there is some disintegration as well as integration, but there is no reason to suppose that the process of integration is at an end, that the clock is running down; indeed, one might suppose that the time clock will only stop when it is wound up as tight as it will go.

At each stage of emergence, then, new characters arise which are not simply related to the properties of the components. Further, all these existences are affected by external conditions. The sciences describing matter and its properties may approach from the point of view of structure, like chemistry ; or of behaviour, like physics: thus forming, as it were, a warp and weft of knowledge. Any simplification in the expression of structure calls for a corresponding complication in the expression of behaviour, and conversely.

The particular aspect of this evolutionary process which is presented to us depends on our local time and space. We have traditionally our three 'kingdoms' - animal, vegetable, and mineral; they might easily be two only, biontic and abiontic; and at some stage there must have been one only, the abiontic. Life exists only at certain levels of evolution and has no meaning outside these, just as temperature has no meaning below the molecular horizon, as it is a symbol of molecular activity.
What, then, is the essential property of living organisms? It lies in the manner of their reproduction, which is always continuous in time and space with an existing organism, and always autocatalytic in form. The process characteristic of living organisms is increase in spatial boundaries followed by splitting, either of the whole unicellular organism or, in higher plants and animals, of 'delegated ' cells. It is clear that the machinery which brings about this type of multiplication must be as simple as a single cell. The significance of the nucleus in heredity is shown by the fact that the paternal influence equals the maternal in animals, where the sperm consists almost entirely of nuclear material, scarcely any cytoplasm being carried over into the new zygote. Taking the analysis a stage further, we find the nucleus formed from smaller bodies, the chromosomes, and the chromosomes in turn composed of still smaller particles, the genes. The genes correspond to the hypothetical units used by Mendel in his classical researches.

Now, when in the genetic investigation of Drosophila about twenty pairs of characters had been found, the fly having four pairs of chromosomes, it became clear that some of the chromosomes must carry more than one pair of factors. From this was developed the theory of the linear order of the factors and the conception of the gene as a particle having a definite place on the chromosome thread. The theory was confirmed by the discovery of non-disjunctions and of translocation: the genes in the translocated portion, said Dr. Bridges, have moved into a new street and have a new street number.

The actual size of a gene is probably of the order of $2-7 \times 10^{-6} \mathrm{~cm}$., smaller than any observed chromosomal structure. Probably each gene forms the central core to a body consisting of a skin and a core with chromonemal sap between. When the chromonema, which lies coiled in the chromosome like a spring in a tube, is uncoiled from its spiral it may be seen as a tangled skein bearing littleknots; so if we cannot see the genes, we can see, as Dr. Bridges said, the tiny houses they live in. From Muller's X-ray work, which shows that a gene affected by irradiation is turned over at one stroke, the structure of the gene would seem to be simple and not compound.

What is the physical rank of the gene? It cannot be below a molecule, and must be built up from the molecules available in the nutrient sap surrounding it. It may possibly be a molecule of a new and unexpected type. 
As regards the process which gives rise to two genes in place of one. two theories are mechanically possible. Either the daughter gene may be built up by the side of the old one, at a catalytic surface, with a point by point correspondence, or the original gene may become doubled and then split. The first would lend itself to a sort of 'zip-fastener' pattern with linear sub-units, as postulated by Serebrovsky. In Dr. Bridges' view, however, the phenomena described by Serebrovsky can be satisfactorily explained on lines of developmental mechanics without the postulate of linear sub-units of the gene. The gene might be a structure shaped like a pancake, having a single layer of molecules built into a definite pattern. A difficulty in the way of assuming that the daughter gene is formed at the surface of a vesicle as repetitions of unitary patches is the fact that genes mutate suddenly as if acting as simple units.

It is probable that the structure of all genes will be found to be of one type. This follows from increasing simplicity with descent in the scale of units. There is far less difference between chromosomes than between organisms, and hence probably far less difference between genes than between chromosomes.

\section{New Game Reserves in South Africa.}

\section{By Prof. H. B. FanthaM.}

$\mathrm{T}$ HE conservation of the natural fauna of a country is a matter of considerable importance. With the advance of agriculture and industrial development, the animals of South Africa, as in other parts of the world, have been in danger of extinction. In fact, within the last hundred years, six of its unique species, the bloubok, quagga, Namaqualand giraffe, Orange River buffalo, blackmaned Cape lion, and the red hartebeest, have become extinct in the Cape Province, and many other species are in danger of extinction. The blesbok, bontebok, and white-tailed gnu only occur on private lands and have been preserved through the efforts of a few individuals.

The South African Government has not been unmindful of the interest and value of its fauna, and a number of large and important game reserves have been established, of which the Kruger National Park in the Transvaal of 5,000,000 acres (more than 7000 square miles) in extent, and the Umfolosi Reserve in Zululand - the home of the fast disappearing white rhinoceros-are perhaps the best known. Recently, on July 3, the Government of the Union of South Africa proclaimed three new game reserves, the constitution of which had been approved by Parliament on May 8.

The largest of these new reserves is termed the Kalahari Gemsbok National Park, in the Division of Gordonia, some distance north of Upington. This Kalahari reserve is about $1,800,000$ acres (some 3000 square miles) in extent. It is an arid area, situated in the Kalahari thorn country between the Oup (Aub) and Nosop (Nossob) Rivers. The elevation is $2000-4000 \mathrm{ft}$. The vegetation consists mainly of thorn bush (species of Acacia), thorntrees such as the cameeldoorn (Acacia giraffae), which is the most characteristic tree of the region, and sparsely spaced tufts of desert grasses. The rivers are frequently dry sandy beds, which flow after rain, but water can always be obtained by sinking shallow wells. This reserve shelters a number of vertebrates, which feed on succulents and xerophytic vegetation, on which they thrive. These include the graceful and handsome gemsbok (Oryx gazella gazella), the red hartebeest, the blue wildebeest, and the springbok. The gemsbok was formerly widely distributed in southern Africa, but now has become relatively rare and even extinct in many parts of the country. They flourish in the Kalahari wastes, where they roam in herds and feed on succulent roots and underground stems dug out by their hoofs. Under protection in the new reserve they should increase in numbers. In addition to the antelopes mentioned, the kudu occurs in the reserve, klipspringer are said to be present, and wild ostrich are known.

The second reserve is the Addo Elephants National Park in the Divisions of Alexandria and Uitenhage, Eastern Cape Province. It comprises an area of more than 11,000 acres, well covered with dense scrub and bush. Portions of the Union Forest Reserve and of a number of farms have been combined to form this game reserve, where the now small herd of the southern geographical race or subspecies of the African elephant can live and propagate. Abundance of Acacia, succulent Portulacaria, aloes, and other succulents provide ample food. A few years ago the Government was obliged to reduce the herd greatly, as they invaded neighbouring farms and did considerable damage. The presence of good watering places in the new reserve, it is hoped, will prevent further damage to cultivated lands by these interesting small elephants. Cape buffalo, which were almost exterminated by rinderpest, still survive in the Addo reserve, and kudu and bushbuck occur in herds. A similar race of elephants occurs in the Knysna reserve, comprising the finest indigenous forests in the Union, and in both the Knysna and the Addo wild pig are abundant, accompanying the elephants and feeding on their droppings, thus aiding in the dispersal of the seeds of trees.

The third reserve is styled the Bontebok National Park. It is situated in the Division of Bredasdorp in the south-western Cape Province. It is a small reserve, some 1700 acres in extent, and will be a sanctuary for the rarest of the South African antelopes, the bontebok (Damaliscus pygargus). For many years this small but most beautiful and richly coloured antelope has been confined to a few farms in this area and has been preserved through the efforts of a few individuals. Formerly it was widely distributed along the coastal strip, and without the active interests of the animal lovers 